
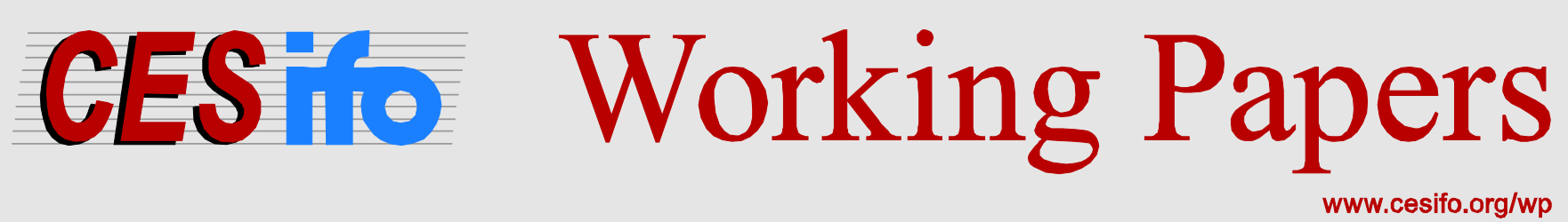

\title{
China's Profits and Losses from Currency Intervention, 1994-2011
}

\author{
Hailong Jin \\ E. Kwan Choi
}

CESIFO WORKING PAPER NO. 4551

CATEgory 8: TRADE POLICY

DECEMBER 2013
An electronic version of the paper may be downloaded
- from the SSRN website:
- from the RePEc website:
- from the CESifo website:
WwW.SSRN.com
www.RePEc.org
www.CESifo-group.org/wp

\section{CESifo}




\title{
China’s Profits and Losses from Currency Intervention, 1994-2011
}

\begin{abstract}
China's currency policy has been criticized for its apparent pursuit of mercantile advantage by artificially stimulating exports, which potentially have adverse effects on other economies. While China's currency policy may have positive output effects, there may be additional profits or losses. This paper computes the annual and cumulative accounting profits from currency intervention since 1994 when China began its currency intervention. It is shown that profits initially were positive but China since 2007 has lost a massive amount from the currency market.
\end{abstract}

JEL-Code: F100.

Keywords: currency intervention, cumulative accounting profits.

\author{
Hailong Jin \\ Department of Economics \\ Texas A\&M University-Kingsville \\ USA - Kingsville, TX 78363 \\ hailong.jin@tamuk.edu
}

\author{
E. Kwan Choi \\ Department of Economics \\ Iowa State University \\ USA - Ames, IA 50011 \\ kchoi@iastate.edu
}

November 2013 


\title{
China's Profits and Losses from Currency Intervention, 1994-2011
}

\begin{abstract}
China's currency policy has been criticized for its apparent pursuit of mercantile advantage by artificially stimulating exports, which potentially have adverse effects on other economies. While China's currency policy may have positive output effects, there may be additional profits or losses. This paper computes the annual and cumulative accounting profits from currency intervention since 1994 when China began its currency intervention. It is shown that profits initially were positive but China since 2007 has lost a massive amount from the currency market.
\end{abstract}

\section{Introduction}

Due to China's mounting currency reserves since the 1990s, its currency policy has been under intense scrutiny. This meteoric rise in China's cumulative trade surplus has provoked much debate concerning China's currency valuation and misalignment. The common view is that "China has intentionally depressed the value of its currency, the renminbi (RMB), to gain unfair advantages in the global market." (Cheung, 2012; McKinnon and Schnabl, 2004) China's currency policy has been criticized because of its possible adverse consequences on other economies.

Most major currencies are free-floating vis-à-vis other currencies, except the renminbi. ${ }^{1}$ China's low renminbi policy may stimulate its economy and reduce unemployment. For example, Gylfason and Schmid (1983) showed that devaluation has positive output effects in a study of ten countries. While currency devaluation raises a country's trade surplus temporarily, reserves cannot grow indefinitely in a stationary equilibrium. Since reserves are bought and sold at different exchange rates. Hence, the central bank may suffer losses from such intervention.

Many monetarists suggest that a central bank should make positive profits from currency intervention to maintain price stability (e.g., Friedman, 1953). They argue that "the central bank has an information advantage over other market participants; it also intervenes to straighten out destabilizing behavior such as "disorderly markets"” (Sweeney, 1997, pp. 1668, Taylor, 2005)." Although few governments admit currency intervention is motivated by profitability, but it is used as a measure of success. For instance, Leahy (1995) and Fatum and Hutchison (2006) analyzed profits of currency intervention by the US and Japan, respectively. However, profits and losses from currency intervention by the China's central bank have not received any attention in the literature.

There are two main differences between speculation by private investors and the People's Bank of China (PBC), China's central bank. First, unlike private speculators, PBC simply prints yuan to buy foreign currencies, and hence does not pay interest. Second, no 
deliverable forward currency market for yuan exists due to its regulated status. ${ }^{2}$ PBC keeps track of the fund to purchase foreign currencies.

The purpose of this paper is to investigate China's profits and losses from currency intervention since 1994 when China began to merge the exchange rates in the swap market and official exchange rates. McKinnon and Schnabl (2009) note that renminbi was inconvertible before 1994. Also, China's trade surplus was negligible in 1994. Thus, we choose 1994 as the base year to compute annual and cumulative profits from currency intervention. Since the central bank may retain any amounts of foreign exchange reserve in any period, we utilize the accounting profit concept from currency intervention in a multiperiod framework (Ghosh, 1997). We demonstrate that while profits from currency intervention were positive in the 1990s, China has lost a phenomenal sum since 2007.

\section{Effects of Yuan Appreciation on China's Trade Surplus}

Assume that China is an open Keynesian economy in each period and trades only with the United States. Due to price rigidity some unemployment exists in its domestic market, and changes in the exchange rate affect its gross domestic product (GDP). Let $\varepsilon$ denote the dollar price of yuan and let $x\left(P, \varepsilon, Y^{*}\right)$ denote China's export in dollars, where $P$ is the price level expressed as yuan per unit of output, and $Y^{*}$ is GDP of the United States. China's GDP, expressed in yuan, is given by:

$$
Y_{i}=C_{i}+I_{i}+G_{i}+\left(x_{i} / \varepsilon_{i}-q_{i}\right)
$$

where $Y, C, I, G$ and $q$ are China's income, domestic consumption, investment, government spending and imports, all expressed in yuan. China's import, $q(P, \varepsilon, Y)$, depends on the price level, exchange rate and its GDP. China is free to choose its dollar peg $\varepsilon$. China's net export $S_{i}$ is defined as

$$
S_{i} \equiv x\left(P_{i}, \varepsilon_{i}, Y_{i}^{*}\right)-\varepsilon_{i} q\left(P_{i}, \varepsilon_{i}, Y_{i}\right)
$$

where $\varepsilon_{i}=P_{i}^{*} / P_{i}$ is the dollar price of yuan, $P^{*}$ is the dollar price per unit of output in the United States, and $Y_{i}$ and $Y_{i}^{*}$ are China's GDP measured in yuan and U.S. GDP measured in dollars in period i, respectively. China's trade surplus $S$ is measured in dollars. Since China is an open Keynesian economy, a yuan devaluation immediately affects domestic price, $P_{i}=P_{i}^{*} / \varepsilon_{i}$. However, yuan depreciation does not affect U.S. GDP, i.e., $Y_{i}^{*}=Y^{*}$. Substituting $\varepsilon_{i}=P_{i}^{*} / P_{i}$ into (1), we get

$$
S_{i} \equiv x\left(P_{i}^{*} / \varepsilon_{i}, \varepsilon_{i}, Y_{i}^{*}\right)-\varepsilon_{i} q\left(P_{i}^{*} / \varepsilon_{i}, \varepsilon_{i}, Y_{i}\right)=X\left(P_{i}^{*}, \varepsilon_{i}, Y^{*}\right)-\varepsilon_{i} Q\left(P_{i}^{*}, \varepsilon_{i}, Y_{i}\right) .
$$

Since foreign price is fixed, $P_{i}^{*}=P^{*}$, and $P^{*}$ will be suppressed henceforth. Let $F(d, r)$ be capital or financial inflow in dollars, including direct investment, portfolio 
investment and short-term capital flow, excluding reserve account activities, where $d$ and $r$ are domestic and foreign interest rate, respectively. A balance of payments (BP) surplus is written as

$$
S_{i}+F_{i}=X\left(\varepsilon_{i}, Y^{*}\right)-\varepsilon_{i} Q\left(\varepsilon_{i}, Y_{i}\right)+F_{i} .
$$

We first consider the gains from currency intervention in a two-period framework. In a stationary equilibrium reserves cannot grow indefinitely. Thus, we assume a balance of payments surplus in one period is offset by a deficit in the next period. Trade surplus arising from any currency intervention directly affects aggregate expenditure. We assume that currency intervention is not sterilized at all. ${ }^{3}$ Equation (1) implicitly defines the equilibrium exchange rate $\varepsilon_{i}^{o}$ in each period; it is the exchange rate which insures zero balance of payments surplus, $X\left(\varepsilon_{i}, Y^{*}\right)-\varepsilon_{i} Q\left(\varepsilon_{i}, Y_{i}\right)+F(d, r)=0$.

Note that $Y_{\mathrm{i}}$ depends on $S_{\mathrm{i}}$ and $\varepsilon_{\mathrm{i}}$, i.e., $Y_{i}=Y_{i}\left(S_{i}, \varepsilon_{i}, Y^{*}\right)$. Equation (2) implicitly defines the exchange rate as a function of trade surplus and U.S. GDP. Thus, the exchange rate also may be expressed as a function of balance of payments surplus,

$$
\varepsilon_{i}=g\left(S_{i}+F_{i}, Y^{*}\right) .
$$

A change in foreign income $Y^{*}$ shifts the trade surplus function. Since $Y^{*}$ is assumed as fixed, we may write the exchange rate as:

$$
\varepsilon_{i}=f\left(S_{i}+F_{i}\right),
$$

where a trade surplus or deficit is expressed in dollars.

We now explore the effect of a yuan devaluation from the equilibrium rate on the trade balance. Note that a change in the exchange rate affects its imports, which in turn affects China's GDP, and hence we may write $Y_{i} \equiv Y_{i}\left(S_{i}\left(\varepsilon_{i}\right), \varepsilon_{i}\right)$. The reduced form of China's import may be written as $Q\left(\varepsilon_{i}\right) \equiv Q\left(\varepsilon_{i}, Y_{i}\left(\varepsilon_{i}\right)\right)$. Differentiating (2) with respect to $\varepsilon$ and suppressing $i$ gives:

$$
S_{\varepsilon}=X_{\varepsilon}-\varepsilon Q_{\varepsilon}-Q,
$$

where subscripts denote partial derivatives. Given that the Marshall-Lerner condition holds, ${ }^{4}$ the trade surplus function is negatively sloped, as shown in Figure 1. This implies $S_{\varepsilon}<0$ and $f^{\prime}(S)<0$. 


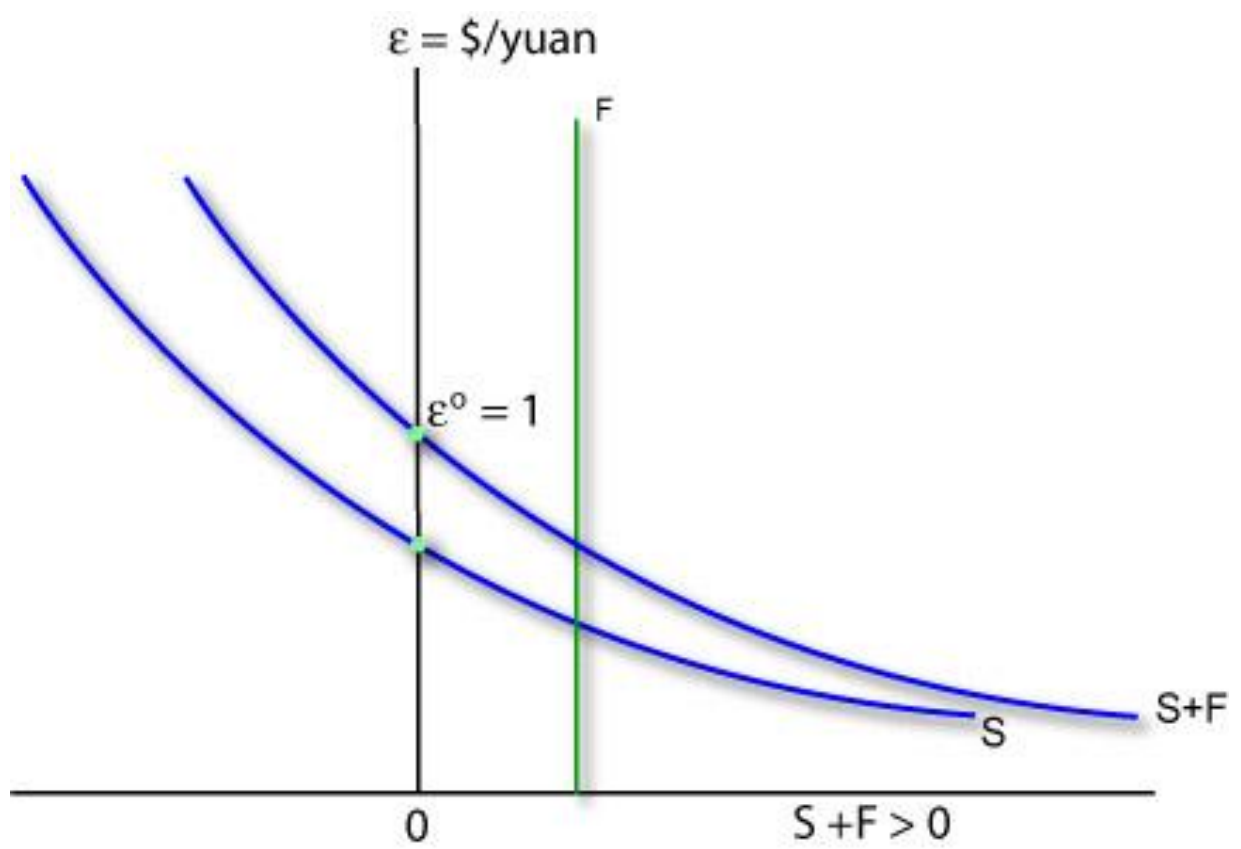

Figure 1: Exchange Rate and Balance of Payments Surplus

In the absence of financial flows, the equilibrium exchange rate is attained where the trade surplus function $\mathrm{S}$ intersects the vertical line at $\mathrm{S}=0$. Recall that $F(d, r)$ is capital inflow. If net capital inflow is positive, it shifts the balance of payments curve, $S+F$, to the right, as shown in Figure 1.

\section{Annual Profits from Currency Intervention}

If China behaves as a price taker in the currency market, an equilibrium exchange rate is that which clears the foreign currency market. If China pegs renminbi at a different rate, a BP surplus or deficit occurs. For instance, China may choose to devalue yuan below the equilibrium and invest the resulting BP surplus in the United States. Nevertheless, reserves cannot grow indefinitely in a stationary equilibrium. To consider the benefits of foreign investment by currency intervention in a simple model, first consider a two period model. China is assumed to incur a trade surplus in the first period, which is invested in dollar assets in the United States, and the proceeds are used in the second period. Subsequently, this assumption is relaxed for multi-period analyses.

Let $S_{1}=S$ denote China's trade surplus in the first period. The yuan cost of a trade surplus of $S$ dollars is $S / \varepsilon_{1}$, where $\varepsilon_{1}$ is the exchange rate in the first period. Trade surplus of $S_{1}$ dollars is invested in US Treasury bills, which grows to $S_{1}(1+r)$ at the end of the second period, where $r$ is the interest rate on the Treasury bills. The yuan cost of net direct investment is $F / \varepsilon_{1}$, which is invested in U.S. Treasury bills. We assume that any foreign investment, whether it is portfolio investment or direct investment, is repatriated in the second period. Thus, the total amount, $(S+F)(1+r)$, is sold in the foreign exchange market in the second period, and the revenue in renminbi is $(S+F)(1+r) / \varepsilon_{2}$, where $\varepsilon_{2}=f(-(S+F)(1+r))$ is the exchange rate in the second period.

The total profit realized from currency intervention is: 


$$
\pi(S+F)=\frac{(S+F)(1+r)}{\varepsilon_{2}}-\frac{S+F}{\varepsilon_{1}}=(S+F)\left(\frac{1+r}{f(-(S+F)(1+r))}-\frac{1}{f(S+F)}\right) .
$$

In order to consider the benefits from currency intervention for more than two periods, we now relax the assumption that the central bank liquidates its currency reserve in any period. That is, the central bank may sell some of its reserve, or buy even more. If any amount of foreign exchange is retained, it is treated as foreign investment at the current pegged rate. Such action, short of liquidation, may contribute to profits or losses in subsequent periods.

\section{Annual Accounting Profits}

Let $C_{i}$ denote the amount of cumulative foreign currency invested in the U.S.

Treasury bills in period i. Assume that the stock of foreign currency reserve at the beginning of period 1 is zero $\left(C_{0}=0\right)$, and hence $C_{1}=S_{1}+F_{1}$. The yuan cost of purchasing $C_{1}$ dollars is $C_{1} / \varepsilon_{1}$. Foreign investment of $C_{1}$ dollars increases to $C_{1}\left(1+r_{1}\right)$, where $r_{i}$ is the US interest rate in period $\mathrm{i}$. Thus, the accounting profit in the first period, which is to be known in the second period, is written as:

$$
\pi_{1}\left(C_{1}, r_{1}, \varepsilon_{1}, \varepsilon_{2}\right)=\frac{(S+F)\left(1+r_{1}\right)}{\varepsilon_{2}}-\frac{S+F}{\varepsilon_{1}}=\frac{C_{1}(1+r)}{\varepsilon_{2}}-\frac{C_{1}}{\varepsilon_{1}} .
$$

Thus, $\pi_{1}\left(S, r_{1}, \varepsilon_{1}, \varepsilon_{2}\right)$ is the accounting profit in period 1 obtained by assessing the end-ofperiod currency reserve, $C_{1}(1+r)=(S+F)(1+r)$, at the unknown exchange rate in the second period, $\varepsilon_{2}$. If the central bank liquidates the reserve in the next period, $\varepsilon_{2}$ can be observed from the trade surplus function. However, the central bank may choose to sell only a part of its reserve or buy even more. We assume that the central bank pegs renminbi each period, and it does not know at what exchange rate renminibi will be pegged thereafter. Thus, in each period, the subsequent exchange rates will be treated as unknown variables.

In the second period, the cumulative investment in the U.S. Treasury bills is $C_{2}=C_{1}\left(1+r_{1}\right)+S_{2}+F_{2}$, where $S_{2}$ and $F_{2}$ are the additional purchases of dollar assets and foreign direct investment in period 2 , both of which can be negative. Since the central bank holds $C_{2}$ in period 2, its yuan cost is $C_{2} / \varepsilon_{2}$. The cumulative foreign investment $C_{2}$ grows to $C_{2}\left(1+r_{2}\right)$ at the end of the second period, which is to be evaluated at the unknown exchange rate, $\varepsilon_{3}$. The market value of the current reserve at the end of period 2 is

$$
\frac{C_{2}\left(1+r_{2}\right)}{\varepsilon_{3}} \text {. }
$$

Thus, the accounting profit in the second period is: 


$$
\pi_{2}\left(C_{2}, r_{2}, \varepsilon_{2}, \varepsilon_{3}\right)=\frac{C_{2}\left(1+r_{2}\right)}{\varepsilon_{3}}-\frac{C_{2}}{\varepsilon_{2}}
$$

Similarly, the annual profit in period $N$ is

$$
\begin{aligned}
& \pi_{N}\left(C_{N}, r_{N}, \varepsilon_{N}, \varepsilon_{N+1}\right)=\frac{\left(C_{N-1}\left(1+r_{N-1}\right)+S_{N}+F_{N}\right)\left(1+r_{N}\right)}{\varepsilon_{N+1}}-\frac{\left(C_{N-1}\left(1+r_{N-1}\right)+S_{N}+F_{N}\right)}{\varepsilon_{N}} \\
& =C_{N}\left(\frac{1+r_{N}}{\varepsilon_{N+1}}-\frac{1}{\varepsilon_{N}}\right)=C_{N}\left(\frac{\left(1+r_{N}\right) \varepsilon_{N}-\varepsilon_{N+1}}{\varepsilon_{N} \varepsilon_{N+1}}\right) .
\end{aligned}
$$

It is important to note that if renminbi appreciates too much, the annual profit will be negative. Only if $(1+r) \varepsilon_{N}>\varepsilon_{N+1}$, the annual profit will be positive. If renminbi appreciates faster than the interest rate, then the annual profit will be negative.

\section{Properties of Annual Accounting Profits}

From (9), annual accounting profits depend on $\varepsilon_{N}, \varepsilon_{N+1}$ and $r_{N}$. Differentiating (9) with respect to $r_{N}$ yields

$$
\frac{\partial \pi_{N}}{\partial r_{N}}=\left(\frac{1}{\varepsilon_{N+1}}+\frac{1}{\varepsilon_{N}^{2}} \frac{\partial \varepsilon_{N}}{\partial r_{N}}\right) C_{N}+\frac{\partial F_{N}}{\partial r_{N}}\left(\frac{1+r_{N}}{\varepsilon_{N+1}}-\frac{1}{\varepsilon_{N}}\right)
$$

Provided that $C_{N}>0$, the first term is positive. For the second term, if $\varepsilon_{i}$ satisfies the fundamental martingale property, i.e., $E\left(\varepsilon_{N+1} \mid \varepsilon_{1}, \cdots, \varepsilon_{N}\right)=\varepsilon_{N}$, then by Jensen's inequality, $E_{N}\left(\frac{1}{\varepsilon_{N+1}}\right) \geq \frac{1}{\varepsilon_{N}}$, and hence $E_{N}\left(\frac{1+r_{N}}{\varepsilon_{N+1}}\right)-\frac{1}{\varepsilon_{N}} \geq \frac{r_{N}}{\varepsilon_{N}}>0$. Since $\frac{\partial F_{N}}{\partial r_{N}}<0$, the second term on the RHS is positive on average. The sign on the RHS is indeterminate.

Differentiating (9) with respect to $\varepsilon_{N}$ and $\varepsilon_{N+1}$, we get

$$
\begin{gathered}
\frac{\partial \pi_{N}}{\partial \varepsilon_{N}}=\frac{\partial S_{N}}{\partial \varepsilon_{N}} \frac{\left(1+r_{N}\right) \varepsilon_{N}-\varepsilon_{N+1}}{\varepsilon_{N} \varepsilon_{N+1}}+\frac{C_{N}}{\left(\varepsilon_{N}\right)^{2}}>0, \\
\frac{\partial \pi_{N}}{\partial \varepsilon_{N+1}}=-\frac{C_{N}\left(1+r_{N}\right)}{\left(\varepsilon_{N+1}\right)^{2}}<0 .
\end{gathered}
$$


Thus, as yuan appreciates, other things equal, expected annual profit increases. On the other hand, as the future value of yuan rises, current profit declines, because a given amount of dollar assets fetches a smaller sum in yuan.

The elasticity of annual profit with respect to the future exchange rate is:

$$
\begin{aligned}
& \eta_{\pi \varepsilon_{N+1}} \equiv \frac{\varepsilon_{N+1}}{\pi_{N}} \frac{\partial \pi_{N}}{\partial \varepsilon_{N+1}}=-\frac{\varepsilon_{N+1}}{\pi_{N}} \frac{C_{N}\left(1+r_{N}\right)}{\left(\varepsilon_{N+1}\right)^{2}} \\
& =-\frac{\varepsilon_{N+1}}{C_{N}\left(\frac{\left(1+r_{N}\right) \varepsilon_{N}-\varepsilon_{N+1}}{\varepsilon_{N} \varepsilon_{N+1}}\right)} \frac{C_{N}\left(1+r_{N}\right)}{\left(\varepsilon_{N+1}\right)^{2}}=-\frac{\varepsilon_{N}\left(1+r_{N}\right)}{\left(1+r_{N}\right) \varepsilon_{N}-\varepsilon_{N+1}} .
\end{aligned}
$$

Suppose the interest rate were .1 percent (as in 2011) and yuan were undervalued by 10 percent. Then a 1 percent yuan appreciation (from $\varepsilon=.9$ to .91 ) reduces profits by

$$
\eta=-\frac{.9 \times 1.001}{1.001 \times .9-.91}=99 \text {. }
$$

Suppose the interest rate is 5 percent and yuan was undervalued by 25 percent. In this situation, a 1 percent yuan appreciation (from $\varepsilon=.9$ to .91 ) reduces profit by 27 percent. These examples suggest that annual profits from currency intervention are very sensitive to exchange rate appreciation, especially when the interest rate is near zero.

\section{Data}

China's foreign exchange reserve and current account data were obtained from the State Administration of Foreign Exchange. ${ }^{5}$ The 1994-2011 yuan-dollar exchange rate data are obtained from the World Development Indicators database. To calculate the annual and cumulative profits in 2011, the yuan-dollar exchange rate on July 2, 2012 was used as proxy for the unknown average exchange rate 2012. Interest rates on U.S. Treasury bills change daily, and the currency reserve data are only annual figures. Thus, a sort of annual average interest rates is needed to compute annual profits from currency intervention. Six-month interest rates on U.S. Treasury bills were used as the annual interest rates. ${ }^{6}$

\section{Annual Accounting Profits Financial Flow}

Based on Equation (9), we calculated China's annual profits from currency intervention for the period, 1994-2011. The results are listed in Table 1. Goldstein and Lardy (2009) noted that before 1985, the swap market was sanctioned by the Chinese government to settle trade transactions. They argue that the official yuan-dollar rate was above the equilibrium market exchange rate, and was used for intergovernmental transactions. Nevertheless, the swap market was helpful to the Chinese government for settling trade transactions at the equilibrium exchange rate. They argued that "the official exchange rate during mid-1990s was probably a reasonable approximation of an equilibrium rate (pp. 6)." 
Also, the method of computing the foreign exchange reserve was changed in 1992 to exclude foreign exchange deposits of state-owned entities with Bank of China. Thus, it would be necessary to choose a base year after 1992. The current account surplus was only about $\$ 5$ billion in 1992, and the current account deficit was about $\$ 12$ billion in 1993. Few economists argue that China's intervention started before 1993. Thus, the period 1993-1994 may be the time in which China refrained from currency intervention. Accordingly, profits and losses from subsequent attempts to moderate exchange rate changes can be computed from 1994.

Table 1 shows annual profits in yuan from currency intervention, which rose to 81 billion yuan in 2000, equal to approximately $1 / 10$ of 1 percent of U.S. GDP, but fell to zero in 2006. Since 2006, China began to incur huge losses, which rose to 546 billion yuan in 2007, 843 billion yuan ( $\$ 125$ billion) in 2010, and 447 billion yuan (\$69 billion) in 2011 . This amount should be compared to the actual current account surplus of \$202 billion in 2011.

Table 1. China’s Annual Profits from Currency Intervention, 1994-2011

\begin{tabular}{|r|r|r|r|r|}
\hline & $\begin{array}{c}\text { Exchange Rate } \\
(\$ / \text { RM })\end{array}$ & $\begin{array}{c}\text { Interest Rate } \\
(\%)\end{array}$ & \multicolumn{1}{c|}{$\begin{array}{c}\text { China FX } \\
\text { (\$Billion) }\end{array}$} & $\begin{array}{c}\text { Annual Profit } \\
\text { (Billion Yuan })\end{array}$ \\
\hline 1994 & 0.116 & 4.64 & 52.9 & 6 \\
\hline 1995 & 0.1198 & 5.56 & 75.4 & 42.2 \\
\hline 1996 & 0.1203 & 5.08 & 107 & 59.3 \\
\hline 1997 & 0.1206 & 5.18 & 142.8 & 59.7 \\
\hline 1998 & 0.1208 & 4.83 & 149.2 & 57.5 \\
\hline 1999 & 0.1208 & 4.75 & 146.2 & 80.9 \\
\hline 2000 & 0.1208 & 5.9 & 165.6 & 58.7 \\
\hline 2001 & 0.1208 & 3.34 & 212.2 & 39.8 \\
\hline 2002 & 0.1208 & 1.68 & 286.4 & 35.1 \\
\hline 2003 & 0.1208 & 1.05 & 403.3 & 29.3 \\
\hline 2004 & 0.1208 & 1.58 & 609.9 & 39.4 \\
\hline 2005 & 0.122 & 3.39 & 818.9 & 2.1 \\
\hline 2006 & 0.1254 & 4.81 & 1066.3 & -546.4 \\
\hline 2007 & 0.1314 & 4.44 & 1528.2 & -6.2 \\
\hline 2008 & 0.144 & 1.62 & 1946 & -98.8 \\
\hline 2009 & 0.1464 & 0.28 & 2399.2 & -843.0 \\
\hline 2010 & 0.1477 & 0.2 & 2847.3 & -447.2 \\
\hline 2011 & 0.1548 & 0.1 & 3181.1 & \\
\hline 2012 & 0.1584 & & & \\
\hline
\end{tabular}

\section{Annual Accounting Profits without Financial Flow}

Financial flows are made to take advantage of different interest rates between countries. The presence of the financial flows indicates that there are temporary differences in the financial 
returns or profitability of investment between the two economies. If no financial flow occurs, i.e., $F_{i}=0$, for all $\mathrm{i}=1, \ldots, \mathrm{N}$, then equation (9) reduces to:

$$
\pi_{N}\left(C_{N}^{S}, r_{N}, \varepsilon_{N}, \varepsilon_{N+1}\right)=C_{N}^{S}\left(\frac{\left(1+r_{N}\right) \varepsilon_{N}-\varepsilon_{N+1}}{\varepsilon_{N} \varepsilon_{N+1}}\right) .
$$

where $C_{N}^{S}$ denotes China's FX caused by trade surplus and is estimated by: $C_{N}^{S}=C_{N-1}\left(1+r_{N-1}\right)+S_{N}$, given $\mathrm{C}_{1993}=0$.

Table 2 shows that the annual accounting profits without the financial flow also were near zero in 2006, and have since decreased to: -641 billion yuan in 2010 . This is somewhat less than -843 billion yuan when the financial flow is included. As expected, if the interest rate differential is negligible, accounting profits should be roughly equal, whether financial flows are included or not.

Table 2. China's Annual Profits from Currency Intervention without Financial Flow, 1994-2010

\begin{tabular}{|r|r|r|r|}
\hline & $\begin{array}{c}\text { Current Account } \\
\text { (\$ Billion) }\end{array}$ & $\begin{array}{c}\text { Estimated FX } \\
\text { (\$ Billion) }\end{array}$ & $\begin{array}{c}\text { Annual Profit } \\
\text { (Billion Yuan) }\end{array}$ \\
\hline 1994 & 7.7 & 7.7 & 0.9 \\
\hline 1995 & 1.6 & 9.6 & 4.1 \\
\hline 1996 & 7.2 & 17.4 & 7.0 \\
\hline 1997 & 37.0 & 55.3 & 23.0 \\
\hline 1998 & 31.5 & 89.6 & 35.8 \\
\hline 1999 & 21.1 & 115 & 45.2 \\
\hline 2000 & 20.5 & 141 & 68.9 \\
\hline 2001 & 17.4 & 166.7 & 46.1 \\
\hline 2002 & 35.4 & 207.7 & 28.9 \\
\hline 2003 & 45.9 & 257.1 & 22.3 \\
\hline 2004 & 68.7 & 328.5 & 15.8 \\
\hline 2005 & 134.1 & 467.7 & 22.5 \\
\hline 2006 & 232.7 & 716.3 & 1.4 \\
\hline 2007 & 354.0 & $1,104.8$ & -395.0 \\
\hline 2008 & 412.4 & $1,566.2$ & -5.0 \\
\hline 2009 & 261.1 & $1,852.7$ & -76.3 \\
\hline 2010 & 305.4 & $2,163.3$ & -640.5 \\
\hline 2011 & 201.7 & $2,369.3$ & -333.1 \\
\hline
\end{tabular}

\section{Cumulative Profits from Currency Intervention}

In each period, the currency reserve is evaluated at the official exchange rate. Thus, the yuan value of the cumulative foreign exchange reserve in period 2 is 
$\frac{C_{2}}{\varepsilon_{2}}=\frac{C_{1}\left(1+r_{1}\right)+S_{2}+F_{2}}{\varepsilon_{2}}$. Note that if China were to liquidate its currency reserve, then $S_{2}+F_{2}=-(S+F)(1+r)$ and the cumulative currency reserve at the end of period 2 reduces to $C_{2}=0$. The total yuan cost of the cumulative foreign exchange reserve in period 2 is: $T_{2}=\frac{S_{2}+F_{2}}{\varepsilon_{2}}+\frac{S_{1}+F_{1}}{\varepsilon_{1}}$.

PBC, as China's central bank, does not pay interest. Unlike private speculators, PBC simply prints yuan to buy foreign currencies. ${ }^{7}$ No deliverable forward currency market for yuan exists due to its regulated status.

Since China holds on to some currency reserve and does not necessarily liquidate it each period, we may consider the cumulative accounting profit which is obtained by assessing the value of currency reserves at the current pegged rate each period. The currency reserve is treated as the bank's investment in dollar assets made during the current period, and should be separated from current profits.

Cumulative Accounting Profit to be realized in period 2 is defined as:

$$
\Pi_{2}=\frac{C_{2}\left(1+r_{2}\right)}{\varepsilon_{3}}-\left(\frac{S_{2}+F_{2}}{\varepsilon_{2}}+\frac{S_{1}+F_{1}}{\varepsilon_{1}}\right) .
$$

Note however, that the exchange rate $\varepsilon_{2}$ depends on $\mathrm{C}_{2}$, and liquidation of the foreign exchange reserve will lower $\varepsilon_{2}$ below the rate that would prevail if it is retained. If the country liquidates its foreign exchange reserve in the second period, then $S_{2}+F_{2}=-\left(S_{1}+F_{1}\right)(1+r)$ and $C_{2}=0$, and equation (15) reduces to (6), and the accounting profit reduces to the actual or realized profit,

$$
\Pi_{1}=\frac{\left(S_{1}+F_{1}\right)\left(1+r_{1}\right)}{\varepsilon_{2}}-\frac{S_{1}+F_{1}}{\varepsilon_{1}} .
$$

\section{Market Value of Foreign Exchange Reserve}

If the country does not liquidate the existing foreign exchange reserve in period 2 , its cumulative reserve balance is

$$
C_{2}=C_{1}\left(1+r_{1}\right)+S_{2}+F_{2},
$$

and the value of the cumulative foreign exchange reserve in yuan at the end of period 2 grows to $C_{2}\left(1+r_{2}\right) / \varepsilon_{3}$. Note that cumulative investment of $C_{3}$ dollars grows to $C_{3}\left(1+r_{3}\right)$, and its market value is: $\frac{C_{3}\left(1+r_{3}\right)}{\varepsilon_{4}}$, which is known in period 4. Likewise, the total yuan 
revenue that would be obtained from liquidating the cumulative foreign exchange reserve at the terminal period $\mathrm{N}$ is:

$$
\frac{C_{N}\left(1+r_{N}\right)}{\varepsilon_{N+1}}
$$

\section{Cumulative Accounting Profits}

The cumulative yuan cost of foreign exchange reserve in period 3 is: $F_{3}=\sum_{i=1}^{3} \frac{S_{i}+F_{i}}{\varepsilon_{i}}$. Thus, the cumulative accounting profit in yuan is:

$$
\Pi_{3}=\frac{C_{3}\left(1+r_{3}\right)}{\varepsilon_{4}}-\left(\frac{S_{3}+F_{3}}{\varepsilon_{3}}+\frac{S_{2}+F_{2}}{\varepsilon_{2}}+\frac{S_{1}+F_{1}}{\varepsilon_{1}}\right) .
$$

Likewise, the total yuan cost up to the terminal period $N$ is:

$$
F_{N}=\sum_{i=1}^{N} \frac{S_{i}+F_{i}}{\varepsilon_{i}}
$$

Cumulative accounting profit in period $N$ is the market value of the currency reserve less cost, i.e.,

$$
\Pi_{N}=\frac{C_{N}\left(1+r_{N}\right)}{\varepsilon_{N+1}}-\sum_{i=1}^{N} \frac{S_{i}+F_{i}}{\varepsilon_{i}}
$$

Note that the cumulative foreign exchange reserve in any period can be obtained by adding the new trade surplus to the cumulative reserve at the end of the previous period. However, in practice, the reported cumulative reserves generally deviate from these derived cumulative reserves.

We now consider an alternative method to compute the cumulative accounting profit, which is obtained by adding annual accounting profits. Note that $C_{2}=C_{1}\left(1+r_{1}\right)+S_{2}+F_{2}$. Thus, $S_{2}+F_{2}=C_{2}-C_{1}\left(1+r_{1}\right)$. Likewise, $S_{N}+F_{N}=C_{N}-C_{N-1}\left(1+r_{N-1}\right), N>1$, and $S_{1}+F_{1}=C_{1}$. Thus, we have 


$$
\begin{aligned}
\Pi_{N} & =\frac{C_{N}\left(1+r_{N}\right)}{\varepsilon_{N+1}}-\sum_{i=1}^{N} \frac{S_{i}+F_{i}}{\varepsilon_{i}} \\
& =\frac{C_{1}\left(1+r_{1}\right)}{\varepsilon_{2}}-\frac{C_{1}}{\varepsilon_{1}}+\frac{C_{2}\left(1+r_{2}\right)}{\varepsilon_{3}}-\frac{C_{2}}{\varepsilon_{2}}+\ldots \\
& =\sum_{i=1}^{N} \pi_{i} .
\end{aligned}
$$

That is, the cumulative accounting profit in each period can be obtained by adding up the annual accounting profits. This method is used in Table 3 to compute the cumulative accounting profits.

Differentiating (20) with respect to $\varepsilon_{\mathrm{N}}$ gives

$$
\begin{aligned}
& \frac{\partial \Pi_{N}}{\partial \varepsilon_{N}}=\frac{\partial \pi_{N}}{\partial \varepsilon_{N}}+\frac{\partial \pi_{N-1}}{\partial \varepsilon_{N}}=\frac{\partial S_{N}}{\partial \varepsilon_{N}} \frac{\left(1+r_{N}\right) \varepsilon_{N}-\varepsilon_{N+1}}{\varepsilon_{N} \varepsilon_{N+1}}+\frac{C_{N}}{\left(\varepsilon_{N}\right)^{2}}-\frac{C_{N-1}\left(1+r_{N-1}\right)}{\left(\varepsilon_{N}\right)^{2}} \\
& =\frac{\partial S_{N}}{\partial \varepsilon_{N}} \frac{\left(1+r_{N}\right) \varepsilon_{N}-\varepsilon_{N+1}}{\varepsilon_{N} \varepsilon_{N+1}}+\frac{S_{N}+F_{N}}{\left(\varepsilon_{N}\right)^{2}}>0 .
\end{aligned}
$$

and from (11) and (12), we also have

$$
\frac{\partial \Pi_{N}}{\partial \varepsilon_{N+1}}=\frac{\partial \pi_{N}}{\partial \varepsilon_{N+1}}<0
$$

Table 3 displays the cumulative accounting profits since 1994. It shows that in the early years of currency intervention, cumulative profits in yuan from currency intervention steadily increased, reaching 543 billion yuan in 2006. PBC began to lose money in 2007 when its cumulative profit was completely wiped out. It has since found it difficult to recover from the mounting losses, which reached 1,399 billion yuan (or about $\$ 217$ billion) in 2011, and are expected to rise further as the yuan appreciates. In 2011, the cumulative accounting loss rose to 1,128 billion yuan, or close to $\$ 179$ billion without the financial flow. Again, inclusion of the financial flow does not make much difference in the cumulative accounting profits.

Table 3. China's Cumulative Profits from Currency Intervention (billion yuan), 1994-2011

\begin{tabular}{|r|r|r|}
\hline & \multicolumn{1}{|l|}{ With Financial Inflow } & \multicolumn{1}{l|}{ Without Financial Inflow } \\
\hline 1994 & 6.0 & 0.9 \\
\hline 1995 & 38.3 & 5.0 \\
\hline 1996 & 81.1 & 12.0 \\
\hline 1997 & 140.4 & 34.9 \\
\hline 1998 & 200.0 & 70.7 \\
\hline 1999 & 257.5 & 115.9 \\
\hline 2000 & 338.4 & 184.8 \\
\hline
\end{tabular}




\begin{tabular}{|l|r|r|}
\hline 2001 & 397.1 & 230.9 \\
\hline 2002 & 436.9 & 259.8 \\
\hline 2003 & 472.0 & 282.1 \\
\hline 2004 & 501.3 & 297.9 \\
\hline 2005 & 540.7 & 320.4 \\
\hline 2006 & 542.7 & 321.8 \\
\hline 2007 & -3.7 & -73.2 \\
\hline 2008 & -9.9 & -78.2 \\
\hline 2009 & -108.7 & -154.5 \\
\hline 2010 & -951.6 & -794.9 \\
\hline 2011 & -1398.8 & -1128.0 \\
\hline
\end{tabular}

In addition to the speculative profits, China's central bank could also have earned profits or incurred losses from sterilizing the incoming and outgoing money flow. A trade surplus in any period increases the money supply when it is converted into renminbi. PBOC can offset this money flow by buying it back through open market operations at the domestic interest rate. When China has a trade deficit, it reduces the money supply, which can also be sterilized by a reverse transaction in the open market. Since China's interest rates change over time, PBOC may earn profits or incur losses from sterilization efforts.

The extent of PBOC's sterilization is not revealed to the public. However, it is possible to compute the annual and cumulative sterilization profits, using the average domestic interest rates each year under various scenarios. When trade deficits and surpluses are completely or $100 \%$ sterilized, the cumulative profits in 2011 would have been $-5,052.6$ billion RMB (or $-\$ 781.1$ billion). Alternatively, when trade surpluses and deficits are sterilized by $50 \%$, then the cumulative profits in 2011 would have reduced to $-3,225.7$ billion RMB (or $-\$ 498.7$ billion). Thus, any effort to sterilize the trade imbalances would have further increased the losses from the intervention efforts.

\section{Concluding Remarks}

Throughout the 1990s, China's profits from currency markets were negligible and China did not intentionally speculate in the currency market. In 1994, China merged the official and swap markets, effectively adopting the exchange rates from the swap market. Initially, the exchange rate rose to the equilibrium level. However, after 1994, the currency peg apparently was below the equilibrium level and China began to accumulate trade surpluses. Such intervention yielded profits until 2006, but the continued appreciation of the yuan resulted in the ballooning of the cumulative losses. This result does not change whether or not the financial flow is included.

The cumulative profits of about 543 billion yuan in 2006 were wiped out completely the next year, and the mounting losses from currency intervention rose to 1,399 billion yuan in 2011. Current account surpluses since 2007 hovered around $\$ 300$ billion, and are expected 
to be above this level, despite the continued appreciation of yuan. If this trend continues, China's losses will continue to mount.

The primary intent of currency intervention may be to stimulate outputs and exports. Nevertheless, PBC may earn profits or incur losses from such intervention attempts. Thus, any benefits from expanded exports should be weighed against the possible losses from currency intervention. 


\section{References}

Cheung, Yin-Wong (2012), "Exchange Rate Misalignment-The Case of the Chinese Renminbi," (forthcoming in Jessica James, Ian W. Marsh and Lucio Sarno (eds.), The Handbook of Exchange Rates.

Fatum, Rasmus and Michael Hutchison, "Effectiveness of Official Daily Foreign Exchange Market Intervention Operations in Japan, Journal of International Money and Finance 25 (2006), 199-219.

Fender, John and Neil Rankin, "A Further Contribution towards Explaining Why Disinflation through Currency Pegging May Cause a Boom," Journal of International Money and Finance, April 2011, v. 30, iss. 3, 516-36.

Filardo, Andrew and James Yetman, "The Expansion of Central Bank Balance Sheets in Emerging Asia: What Are the Risks?" BIS Quarterly Review, June 2012. Available at SSRN: http://ssrn.com/abstract=2128558.

Friedman, Milton, The Case for Flexible Exchange Rates, Essays in Positive Economics, University of Chicago Press, 1953, Chicago.

Ghosh, Dilip K., "Profit Multiplier in Covered Currency Trading with Leverage," Financial Review 32 (1997), 391-409.

Ghosh, Dilip K. and Augustine C. Arize, "Profit Possibilities in Currency Markets: Arbitrage, Hedging and Speculation," Financial Review 38 (2003), 473-496.

Goldstein, Morris and Nicholas R. Lardy, "Chapter 1, Evolution of China's Exchange Regime in the Reform Era," in The Future of China's Exchange Rate Policy, 2009, also http://bookstore.piie.com/book-store/4167.html (accessed December 30, 2011).

Gylfason, Thorvaldur and Michael Schmid, "Does Devaluation Cause Stagflation?, Canadian Journal of Economics 16 (1983), 641-654.

Leahy, Michael P., "The Profitability of U.S. Intervention in the Foreign Exchange Markets," Journal of International Money and Finance (December 1995), 823-844.

Ma, Guonan, Xiandong Yan and Xi Liu (2011) "China's evolving reserve requirements," BIS Working Paper 360.

McKinnon, Ronald and Gunther Schnabl, "China's Financial Conundrum and Global Imbalances," China Economist (21), July-August 2009, 65-77.

McKinnon, Ronald and Gunther Schnabl, "The East Asian Dollar Standard, Fear of Floating and Original Sin," Review of Development Economics 8 (2004), 331-360.

Sweeney, Richard J., "Do Central Banks Lose on Foreign-Exchange Intervention? A Review Article," Journal of Banking \& Finance 21 (1997), 1667-1684.

Taylor, Dean, "Official Intervention in the Foreign Exchange Market, or, Bet Against the Central Bank," Journal of Political Economy 90 (1982), 356-368.

Taylor, Mark P., "Official Foreign Exchange Intervention As a Coordinating Signal in the Dollar-Yen Market," Pacific Economic Review 10 (2005), 73-82.

World Development Indicators database, http://data.worldbank.org/, accessed January 12, 2012.

\section{Endnotes}

${ }^{1}$ Unlike Japan, China does not allow its citizens to invest in dollar assets. 
${ }^{2}$ Because of recent internationalization attempts, China is allowing the offshore market for the RMB-denominated assets. Also, nondeliverable forwards (NDFs) exist in yuan. However, not all non-convertible currencies have a NDF market, which exists in some countries where forward foreign exchange trading is banned by the government.

${ }^{3}$ Complete nonsterilization implies that the money supply has increased with the increase in foreign exchange reserves. Since the model assumes a Keynesian open economy, an increase in money supply has no effect on the economy-wide inflation rate. In practice, the increases in foreign exchange reserves in China has been largely offset by increases in central bank issued paper and required reserves. Ma, Yan and Liu (2011) note that increasing reserve requirement is typically a lost-cost option "because the central banks pay little or not interest," but "below-market remuneration on required reserves acts as a tax on domestic banks." See also Filardo and Yetman (2012).

${ }^{4}$ China's trade surplus in dollars decreases as yuan appreciates if $\eta_{X \varepsilon}+\eta_{Q \varepsilon}<1$, where $\eta_{X \varepsilon} \equiv(\partial X / \partial \varepsilon)(\varepsilon / X)$ and $\eta_{Q \varepsilon} \equiv-(\partial Q / \partial \varepsilon)(\varepsilon / Q)$ denote elasticity of exports and imports with respect to the exchange rate $\varepsilon$. It can be shown that China's trade surplus in yuan also decreases under the same condition.

${ }^{5}$ This data excludes gold from the international reserve assets.

${ }^{6}$ Interest rate data on the 1-year Treasury bills were not available in certain years.

${ }^{7}$ This constitutes an increase in money supply to affect the yuan-dollar exchange rate. PBC issues a certain amount of new money each year. Some of it is used to buy foreign exchange from commercial banks, and is called the "Funds outstanding for foreign exchange" by PBC. 